\title{
Effect of Natural Gas Fuel Addition on the Oxidation of Fuel Cell Anode Gas
}

\author{
Randall S. Gemmen \\ Edward H. Robey, Jr.
}

November 1999

U.S. Department of Energy

National Energy Technology Laboratory

Pittsburgh, Pennsylvania

Morgantown, West Virginia

NETL's Customer Service Line: (800) 553-7681

NETL's Homepage: http:/www.netl.doe.gov/ 


\section{Disclaimer}

This report was prepared as an account of work sponsored by an agency of the United States Government. Neither the United States Government nor any agency thereof, nor any of their employees, makes any warranty, express or implied, or assumes any legal liability or responsibility for the accuracy, completeness, or usefulness of any information, apparatus, product, or process disclosed, or represents that its use would not infringe privately owned rights. Reference herein to any specific commercial product, process, or service by trade name, trademark, manufacturer, or otherwise does not necessarily constitute or imply its endorsement, recommendation, or favoring by the United States Government or any agency thereof. The views and opinions of authors expressed herein do not necessarily state or reflect those of the United States Government or any agency thereof.

Available to DOE employees and contractors from the Office of Scientific and Technical Information, P.O. Box 62, 175 Oak Ridge Turnpike, Oak Ridge, TN 37831; prices are available by phone: (423) 576-8401; fax: (423) 576-5725; or e-mail: reports@ adonis.osti.gov.

Available to the public from the National Technical Information Service, U.S. Department of Commerce, 5285 Port Royal Road, Springfield, VA 22161; phone orders accepted at (703) 4874650 . 


\begin{abstract}
The anode exhaust gas from a fuel cell commonly has a fuel energy density between 15 and $25 \%$ that of the fuel supply, due to the incomplete oxidation of the input fuel. This exhaust gas is subsequently oxidized (catalytically or non-catalytically), and the resultant thermal energy is often used elsewhere in the fuel cell process. Alternatively, additional fuel can be added to this stream to enhance the oxidation of the stream, for improved thermal control of the power plant, or to adjust the temperature of the exhaust gas as may be required in other specialty cogeneration applications. Regardless of the application, the cost of a fuel cell system can be reduced if the exhaust gas oxidation can be accomplished through direct gas phase oxidation, rather than the usual catalytic oxidation approach. Before gas phase oxidation can be relied upon however, combustor design requirements need to be understood. The work reported here examines the issue of fuel addition, primarily as related to molten-carbonate fuel cell technology. It is shown experimentally that without proper combustor design, the addition of natural gas can readily quench the anode gas oxidation. The Chemkin software routines were used to resolve the mechanisms controlling the chemical quenching. It is found that addition of natural gas to the anode exhaust increases the amount of $\mathrm{CH}_{3}$ radicals, which reduces the concentration of $\mathrm{H}$ and $\mathrm{O}$ radicals and results in decreased rates of overall fuel oxidation.
\end{abstract}




\section{Contents}

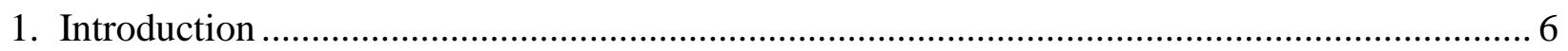

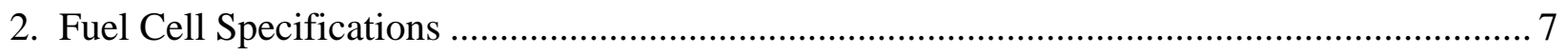

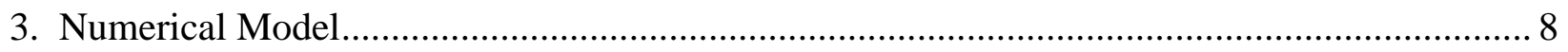

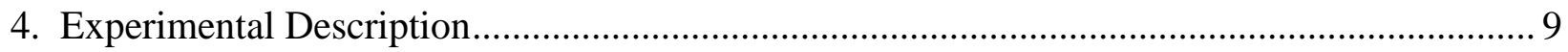

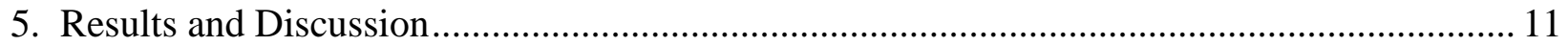

Table 1. Model results using 4\% $\mathrm{CH}_{4}$ at the inlet to the combustor (disabled) .............. 16

Table 2. Model results using $4 \% \mathrm{CH}_{4}$ at the inlet to the combustor (enabled) ................ 16

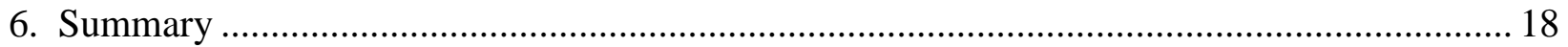

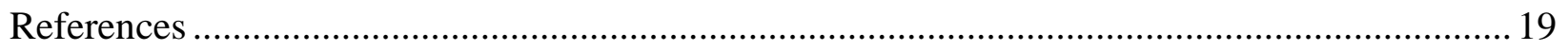




\section{List of Figures}

1: Experimental and Model Results (CASAM, Combustion

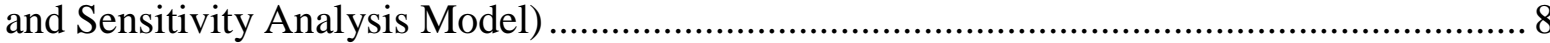

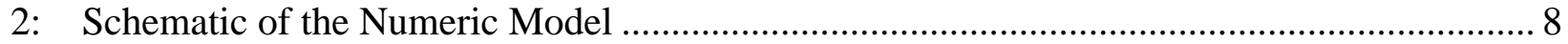

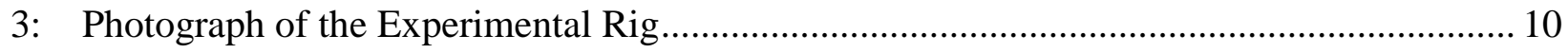

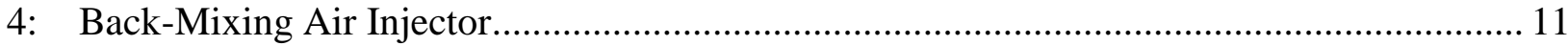

5: $\quad$ Effect of Natural Gas Addition on Combustion............................................................... 12

6: Effect of Natural Gas and Air Addition (stoichiometric pre-mix) .................................. 13

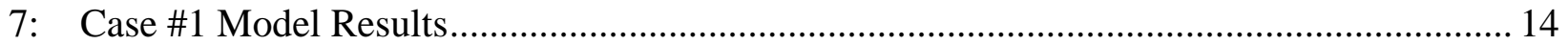

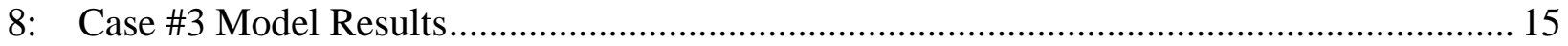

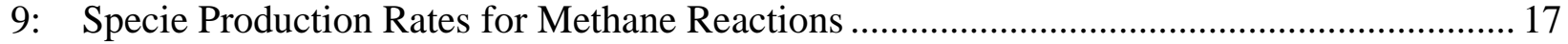

10: Net Specie Production Rates for Two Combustor Sections ............................................. 18 


\section{Introduction}

Fuel cells emit a relatively low fuel energy density gas (approximately 1.1 to $1.5 \mathrm{MJ} / \mathrm{m}^{3}$ [30 to 40 Btu per standard cubic foot]), which results from the incomplete oxidation of fuel components passing through the anode sections. (Unless otherwise noted, all fuel energy densities are given at their higher heating values.) This residual fuel needs to be oxidized to achieve acceptable pollutant emissions and overall thermal efficiency. Often, catalytic reactors are selected to complete the oxidation of this gas stream. Such systems are expensive and add to the initial cost of the fuel cell balance of plant, as well as subsequent operational costs. By improving our understanding of the anode exhaust gas oxidation processes, cheaper and easier to operate combustion systems can be achieved. Finally, current conceptual system designs integrate fuel cells with a gas turbine engine; i.e., the hybrid cycle (Liese et al. 1999; Williams et al. 1995). To achieve optimal performance with projected thermal efficiencies near $75 \%$, these systems will require the oxidation of the anode exhaust gas prior to entering the gas turbine system. Hence, understanding the combustion behavior of low energy mixtures will aid the future development of these systems as well.

This paper investigates the effect of natural gas addition on the gas phase oxidation behavior of molten-carbonate fuel cell anode exhaust. Both a numerical model and an experimental study were employed to predict and assess the anode gas oxidation under natural gas addition. Section 2 provides a general description of a fuel cell, and presents parameter values relevant to this study. It also provides information on past work in non-catalytic anode gas oxidation. The details of the numerical model are presented in Section 3, and the experiment is described in Section 4. Results from both the numerical model and experiment are presented in Section 5, followed by a summary of the main findings in Section 6 . 


\section{Fuel Cell Specifications}

Fuel cells convert chemical energy directly into electrical energy through electrochemical reactions (Kordesch and Simader 1996). For molten carbonate fuel cells, natural gas is mixed with water vapor in a reforming process to create hydrogen and carbon monoxide, which are then supplied to the anode section of a cell. Carbonate ions passing through the electrolyte from the cathode react with the hydrogen (and to some extent carbon monoxide as well) at the surface of the anode at approximately $950 \mathrm{~K}\left(1250{ }^{\circ} \mathrm{F}\right)$. During the reaction, electrons from the carbonate ions are given up to provide a current to drive an external load.

The electrochemical reaction of the hydrogen and carbon monoxide in the anode section is incomplete, causing residual hydrogen and carbon monoxide to exit the anode. Overall fuel conversion at the anode may be near $75 \%$ for molten carbonate fuel cells, which means that $25 \%$ of the original fuel energy exits as hydrogen and carbon monoxide. Due to the flow of carbonate molecules to the anode ( 3 carbonate: 1 methane @ 75\% fuel utilization) and the water added for reforming methane, the anode exhaust gas is highly diluted with carbon dioxide and water vapor. There is very little published experimental data on fuel cell anode gas composition; however, most models assume near equilibrium concentrations at the anode exhaust temperature. Therefore, for the current study, a base anode exhaust composition is given as $7.8 \%$ hydrogen and $5.5 \%$ carbon monoxide, with the balance being $48 \%$ carbon dioxide and $39 \%$ water vapor-i.e., near equilibrium at $950 \mathrm{~K}$. This gas mixture has a fuel energy density (or heating value) near $1.5 \mathrm{MJ} / \mathrm{m}^{3} \mathrm{HHV}$ (40 BTU per standard cubic foot).

Because of the unique gas composition, temperature, and fuel energy density, the best strategy for direct gas phase oxidation is not readily evident from past combustion work. In Gemmen (1997), an air-staged combustor was investigated numerically to determine the optimal distribution of air, and experimentally to determine the minimum fuel energy density for ignition over a range of temperatures. Some results from that study are shown in Figure 1. It is clear that at the $950 \mathrm{~K}$ operating condition, a fuel energy density above $1.5 \mathrm{MJ} / \mathrm{m}^{3}$ will be required to reliably achieve gas phase oxidation. This value is too close to the standard operating condition just described to be considered reliable. (Due to upsets that can occur in practical systems, one may not always be guaranteed ignition.) The objective for combustor developers is to determine the necessary combustor requirements so that, at a given operating temperature, the lowest energy density gas can be oxidized. In short, any technique that provides ignition curves substantially lower than those shown in Figure 1 should be considered. In an attempt to achieve such results, the current work premixed natural gas with the anode exhaust prior to entering the air-staged combustor with the expectation that sufficient natural gas addition could effectively lower the fuel energy needed from the anode gas. 


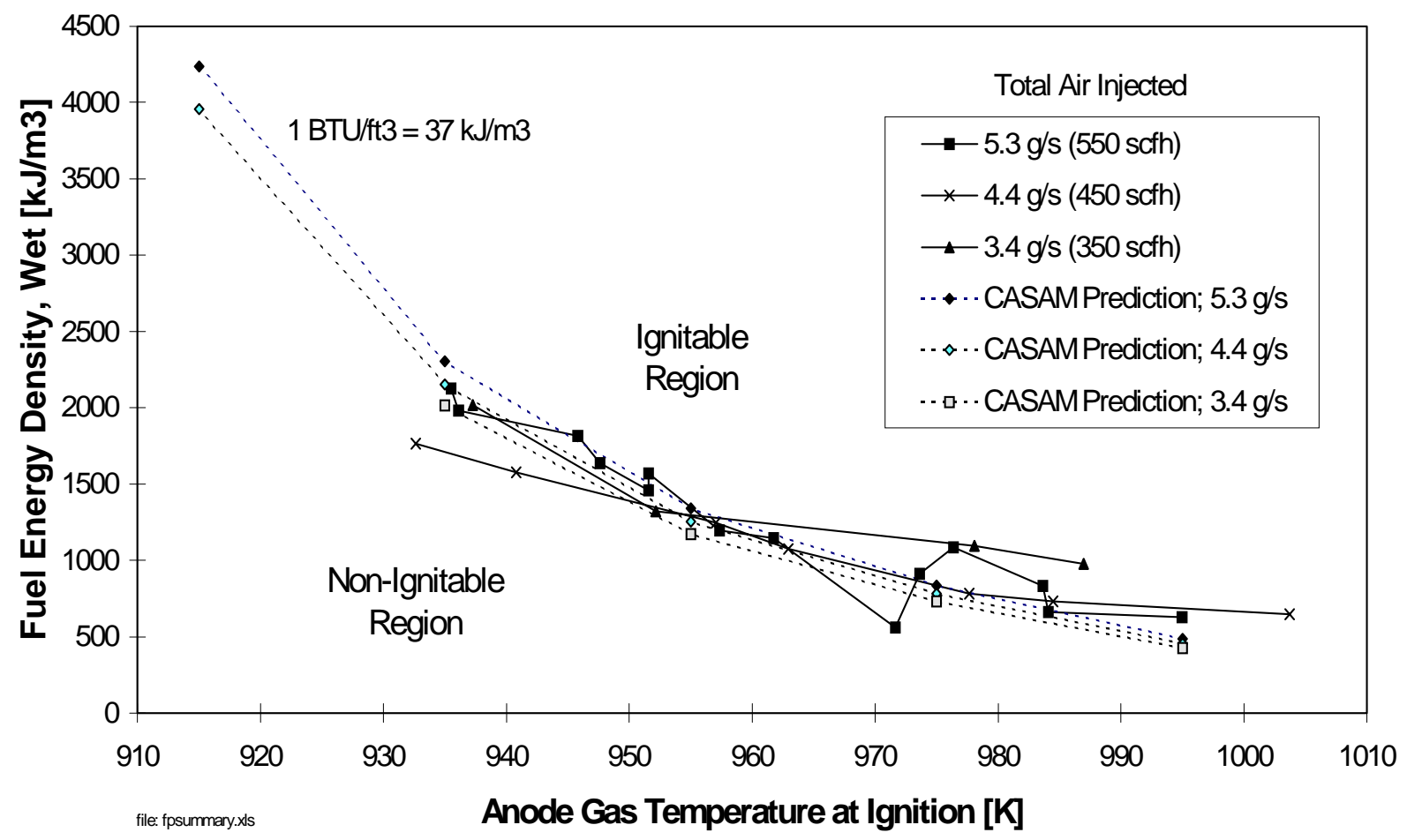

Figure 1. Experimental and Model Results

(CASAM, Combustion and Sensitivity Analysis Model)

for an air-staged combustor (Gemmen 1997

\section{Numerical Model}

The simplified numerical model employed in this study, called the Combustion and Sensitivity Analysis Model (CASAM), is described in detail elsewhere (Gemmen 1997). In short, the model considers the detailed evolution of the fuel species inside a combustor composed of a series of adiabatic plugflow-reactor sections (Figure 2). For this plug-flow-reaction, the system is considered to be one-dimensional and non-diffusive. For the present work, 11 plug-flow-reactor sections are used. At the inlet to each combustor section, air is injected at some specified rate and rapidly mixed with the incoming gas flowing from the previous combustor section. The mixture then undergoes reaction until it leaves the combustor section. The model employs the Miller-Bowman reaction set (Miller and Bowman 1989), and thermodynamic data from the Chemkin

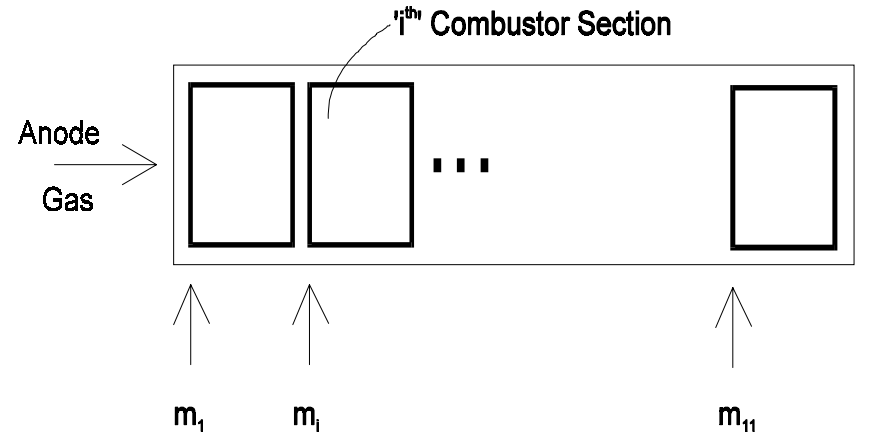

Figure 2. Schematic of the Numeric Model (where $\mathrm{m}_{\mathrm{i}}$ denotes the mass rate of air injected at section ' $i$ ') 
database (Kee at al. 1989). Because of the parabolic mathematical nature of the proposed model, the solution of the problem is achieved by starting at the first combustor, and sequentially assessing the solution for each downstream combustor. The solution of each plug-flow-reactor was determined by the LSODE routine (Radhakrishnan and Hindmarsh 1993). The numerical routines were written in 32-bit $\mathrm{C}++$, and executed on a $233 \mathrm{MHz}$ PC. The model was validated by comparisons with Mulholland et al. (1992) and direct comparisons with other Chemkin model results for problems representative of the current study.

In spite of the fact that diffusion processes are absent within the model's PFR sections, the present model should be suitable for these two studies, since the main concern is the prediction of a self-ignitable combustor. For such practical results where the greatest importance lies in assessing the pre-ignition stage of the process, the role of diffusion transport (whether molecular or turbulent) in the reaction processes leading up to ignition is not significant (Mulholland et al. 1992). It is not until the species and temperature gradients become very large near the flamefront that diffusion becomes significant. However, by then the model has sufficiently predicted the ignition event. In general, diffusion can play a significant role in making a combustor suitable for a given application as it can support the existence of hysteresis between ignition and extinction. With hysteresis, the combustion of fuel, once lit within the combustor, is found to remain stable in spite of slight upsets in inlet conditions. This type of stability information cannot be predicted with the current model.

As discussed in Gemmen (1997) and employed for the present work, optimized air injection profiles were determined numerically for a given anode exhaust gas composition and temperature, using the so-called "local" procedure. This procedure assumes that the optimal air injection profile for the overall combustion system can be found by determining the air injection at each individual section, ' $\mathrm{i}$ ', that produces the lowest total flow rate of fuel components, $\mathrm{z}_{\mathrm{i}}$, exiting that section. Hence, the solution procedure moves sequentially downstream through the combustion system, starting at the inlet, and locally determines the optimal air injection flow rate. Because this procedure only passes through all combustor sections once, it is very efficient and offers fast solutions. In the work reported in Gemmen (1997), such a solution was found to be close to the result determined using a more generalized optimization procedure.

\section{Experimental Description}

The goal of the experimental work was to replicate as closely as possible the low energy density (LED) exhaust gas conditions emitted from a molten-carbonate fuel cell, and then establish, via testing, the required fuel energy density to achieve ignition for a given gas temperature and air injection profile. The hot LED fuel mixtures were generated by partial oxidation of a fuel rich $\mathrm{CH}_{4}, \mathrm{O}_{2}$ and $\mathrm{CO}_{2}$ mixture within a reactor called the gas generator. Samples of the product gas entering the air-staged reactor were taken periodically and analyzed to determine its composition. The dry-volume basis composition of the LED gas was 0-30\% carbon monoxide and $0-10 \%$ hydrogen, with the remainder being carbon dioxide. Water vapor comprised approximately $46 \%$ of the total volume of the LED gas. The composition and fuel energy density of the product LED gas was controlled by varying the flow rate of natural gas entering the gas generator, with the flow rates of oxygen and carbon dioxide held constant. 
Further details of the gas generator design and operation can be found in Gemmen and Robey (1998).

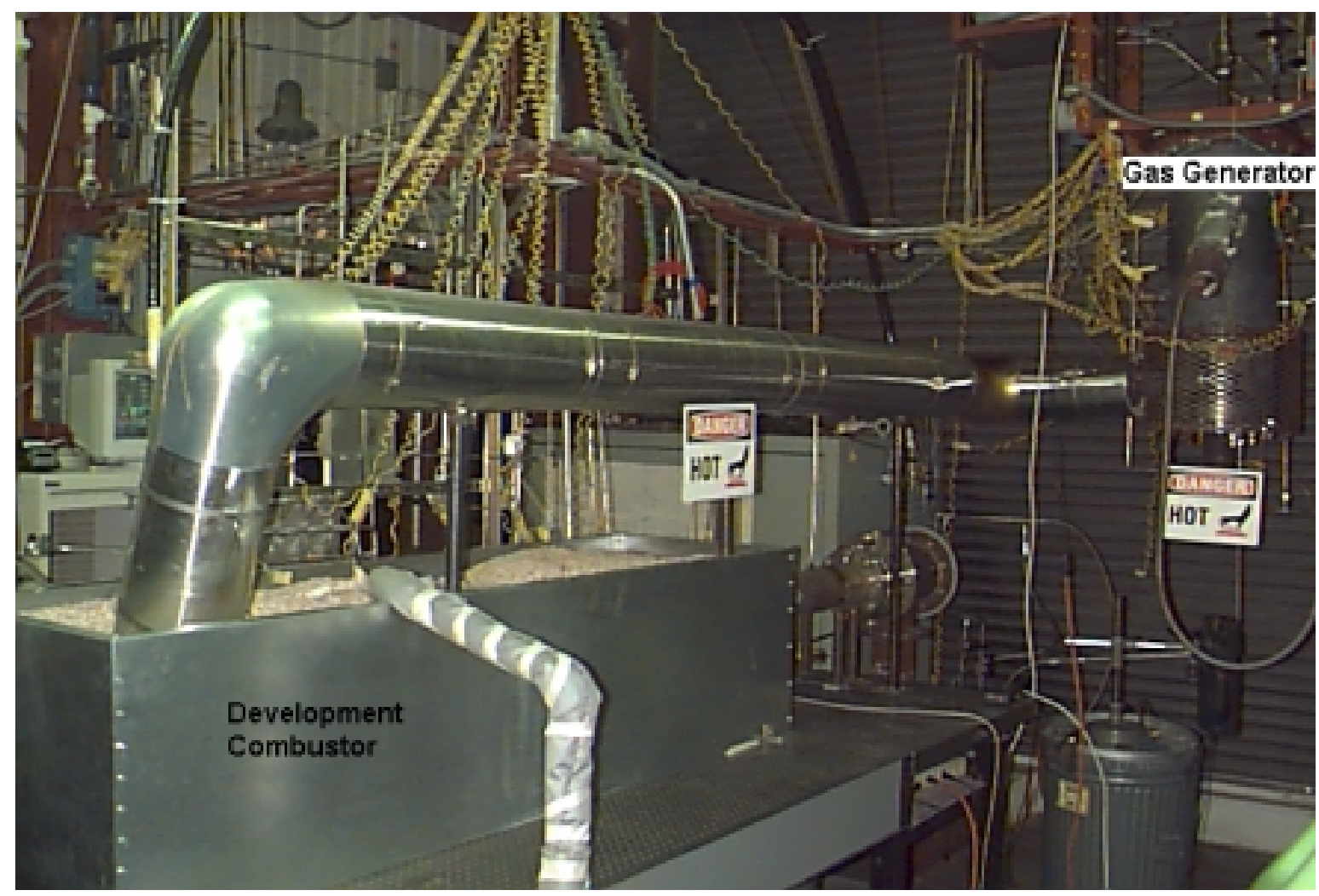

Figure 3. Photograph of the Experimental Rig

The hot LED fuel produced in the gas generator flowed through a 15 -foot long 2-inch diameter insulated pipe to a 5-inch diameter by 9.5-foot long insulated development combustor. The interface between the 2-inch and 5-inch pipes provided a step expansion for the inlet gas, and defined the inlet to the development combustor. Figure 3 shows a photograph of the development combustor embedded in a box of vermiculite insulation. The development combustor employed air-staged-injection to facilitate ignition and combustion of the LED fuel. Combustion air was injected into the development combustor at 11 locations along its axis, with the first injector located $0.34 \mathrm{~m}$ downstream from the inlet step expansion. Figure 4 shows one of the back-mixing air injectors employed at these 11 locations. It was discovered that if the total quantity of air required to burn the LED fuel was mixed with the LED fuel as it entered the development combustor, it would cool the mixture too much, to the point where reactions necessary for ignition and combustion would be quenched. Addition of combustion air in stages permitted the reactions to start with the gradual evolution of heat enhancing downstream reactions. The largest proportion of the combustion air was added downstream after sufficient energy had been liberated, with the result that near complete oxidation of the fuel components could be achieved. 
Ignition and combustion of the LED fuel were dependent upon the energy content of the fuel, the average temperature of the reactor, and the quantity and distribution of combustion air. For a fixed air distribution, the LED energy density required for ignition decreased as reactor temperature was increased. The relationship between energy density and reactor temperature was used to characterize the LED ignition behavior. To arrive at this relationship, a series of fuel-production tests were conducted at a variety of reactor temperatures. A fuel-production test consisted first of reducing the flow of natural gas supplied to the gas generator to well below stoichiometric levels so that the heating value of the LED fuel being delivered to the development combustor was essentially zero. Then, by slowly increasing the natural gas flow rate, the energy density of the LED fuel was increased until ignition was detected on thermocouples distributed axially in the development combustor. At the point where ignition occurred, the energy density and temperature of the supplied LED fuel were recorded as a single X-Y data pair on the ignition curve. These fuel-production tests were repeated at various temperatures to provide an ignition curve over an associated fuel energy density range. Again, Figure 1 shows examples of such curves.

\section{Results and Discussion}

Unless otherwise noted, the "base" configuration used for the experimental work and model

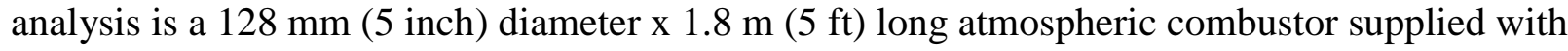
an anode gas stream at the base conditions described in Section 2 and flow rate of $9.3 \mathrm{~g} / \mathrm{s}$ (960 $\mathrm{scfh})$. The air for oxidation is supplied at $300 \mathrm{~K}$ and atmospheric pressure.

In an effort to improve the ignition of the LED fuel, several experiments were performed in which small amounts (<4\% of the total LED flow) of supplemental fuel (natural gas or propane) was injected into the development combustor in various configurations. For some cases, the fuel was premixed with a stoichiometric amount of air. The data presented here are for natural gas (or premixed natural gas + air) injected into the development combustor through a $9.52 \mathrm{~mm}(3 / 8$ inch) diameter tube extending down the center of the LED inlet and ending at the step expansion. There it mixes with the LED fuel before any air is injected into the combustor (i.e., what will be referred to as a premixed mode). All these tests were performed while using the air injection strategy that provided the best (lowest curve) ignition behavior-i.e., the 'baseline' case which used an air flow rate of $235 \mathrm{slpm}(550 \mathrm{scfh})$ into the development combustor.

Figure 5 shows the effect of natural gas addition on the ignition curve for two separate cases, one with a flow rate of $2.36 \mathrm{slpm}(5 \mathrm{scfh})$, and another with a flow rate of $4.72 \mathrm{slpm}(10 \mathrm{scfh})$. 
For comparison, the base case without natural gas addition is also shown. Here the ignition

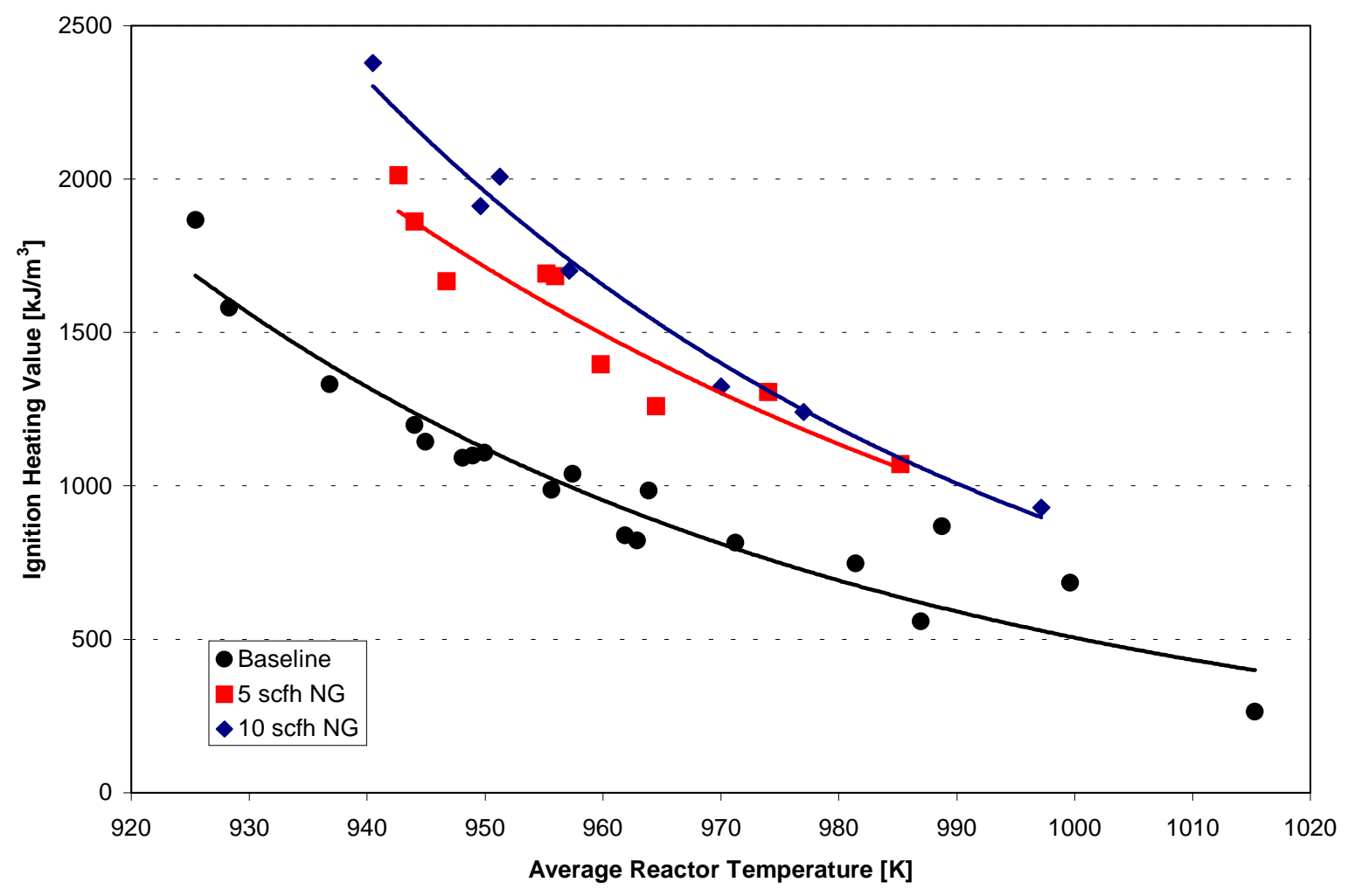

Figure 5. Effect of Natural Gas Addition on Combustion

energy (Ignition Heating Value) is still based strictly on the energy content of the anode gas mixture alone. As Figure 5 shows, the fuel energy density of the anode gas required for ignition increases significantly due to the addition of even small amounts of fuel.

Figure 6 shows similar results, but now illustrates the effect of the addition of natural gas premixed with a stoichiometric amount of air. While these results show more variation in the data, they indicate clearly that adding fuel tends to inhibit ignition (and therefore oxidation) of the gas mixture. 


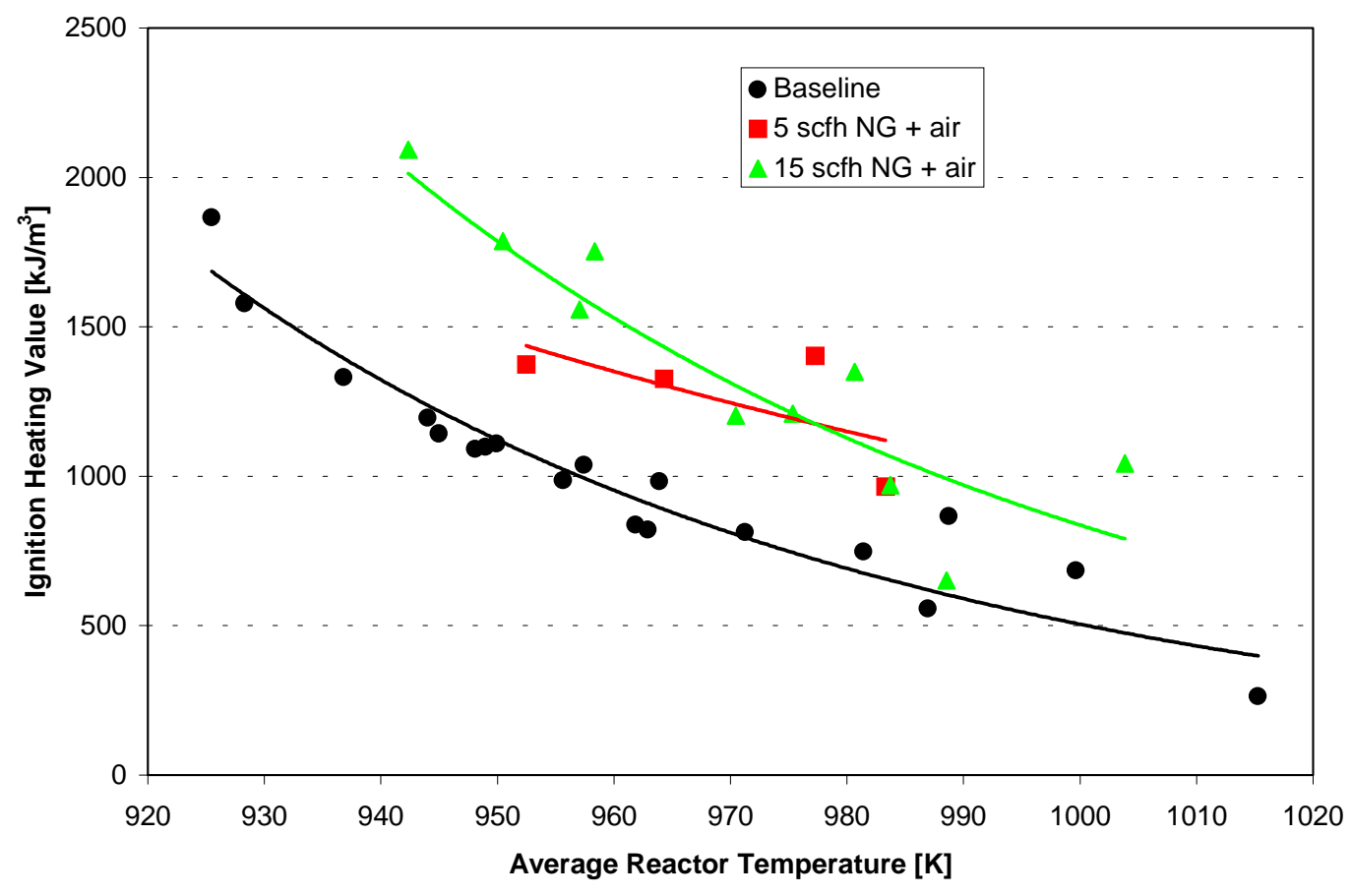

Figure 6. Effect of Natural Gas and Air Addition

(stoichiometric pre-mix)

Results from these few experiments indicate that premixing natural gas to enhance anode gas oxidation does not appear feasible. Further, for applications that require improved exhaust gas temperature control, something other than the simple configuration employed here will be needed if the control is to be achieved by natural gas addition. It is easy to see that it may be more beneficial to simply oxidize the natural gas directly in a separate combustor (which can be made relatively small given the relative magnitudes of natural gas flow vs. anode gas flow). Once the natural gas is oxidized in a separate combustor and then mixed with the anode gas, it becomes a hot energy source to support further reaction of the anode gas. Since one of the benefits of fuel cells is their low NOx, this type of arrangement would need to be performed carefully to avoid adding to the plant's emissions. The concept of burning natural gas separately before mixing with the anode stream was examined as part of our follow-on work (not to be discussed here), and showed improved performance.

To investigate the cause for the quenching seen by the addition of natural gas, the previously described CASAM model was used to look at the detailed reactions, with particular focus on those related to methane. The model was first used to assess an optimized air profile for a case with a pure anode exhaust gas mixture at the 'base' condition-Case \#1. These results are shown in Figure 7, and indicate that the oxidation is best achieved by adding a small amount of air at the inlet, letting the chemistry evolve to provide increased temperature and radicals, then gradually increasing the air input until near complete oxidation is achieved. 


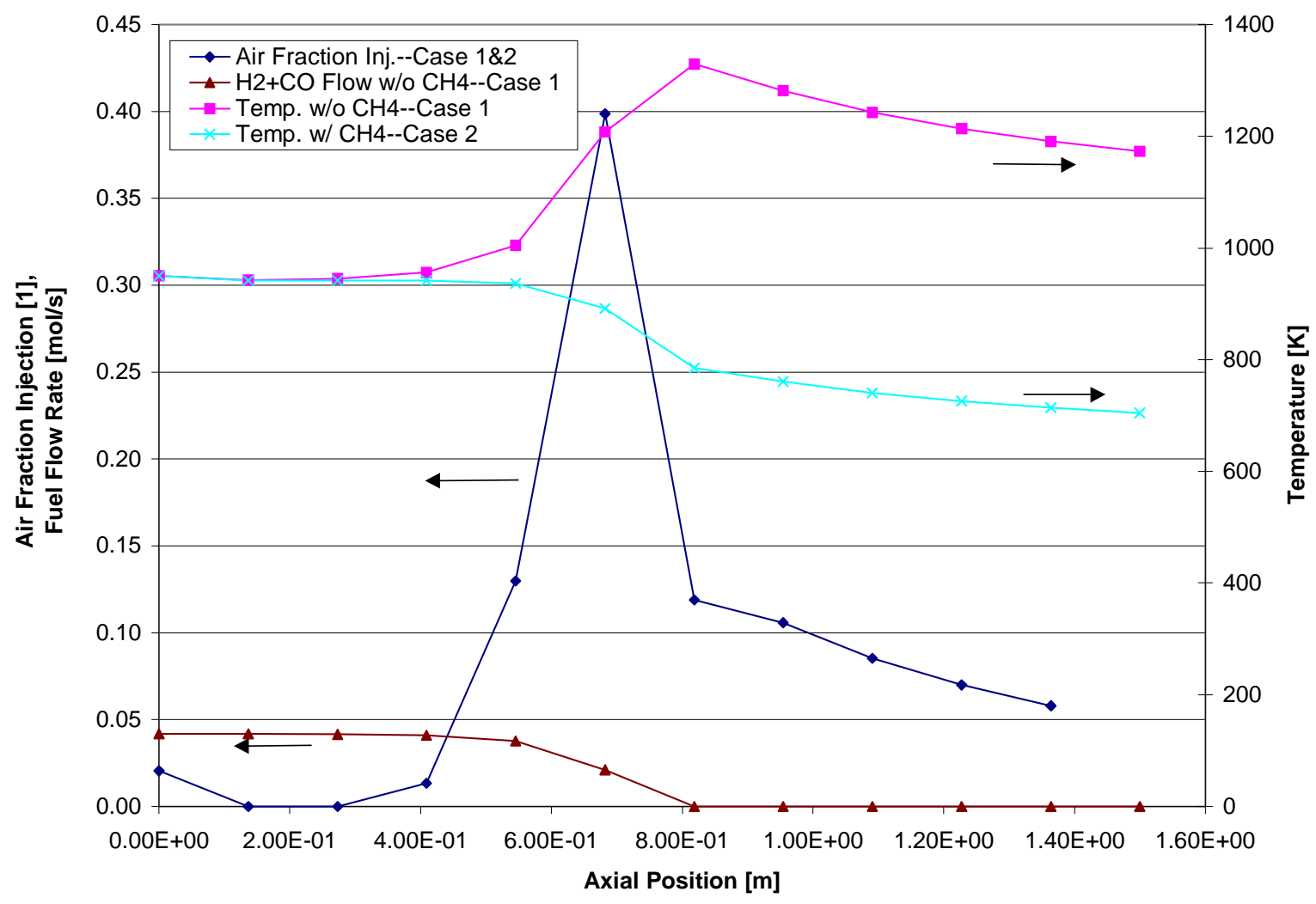

Figure 7. Case \#1 Model Results

(Showing the optimized air profile for the oxidation of a pure anode exhaust gas mixture. The fuel components were essentially fully oxidized. Also shown is the temperature profile for Case \#2 where $4 \% \mathrm{CH}_{4}$ was added, and where the same air profile was employed. For this latter case, there was essentially zero oxidation, and the temperature of the gas is significantly reduced.)

Using the same air profile predicted by Case \#1, an additional case (Case \#2) was modeled where $\mathrm{CH}_{4}$ was premixed with the anode stream to determine whether a benefit could be obtained by increasing the anode gas energy density. As shown via the temperature data in Figure 7, with the addition of $4 \% \mathrm{CH}_{4}$, the oxidation of the anode gas is nearly completely quenched. To resolve the dominant features of the reaction process that lead to this result, a simulation was performed in which all $\mathrm{CH}_{4}$ aspects of the Miller-Bowman reaction set were disabled - that is, $\mathrm{CH}_{4}$ acted purely as an inert diluent. The results showed that the oxidation remained quenched, which indicated that the mere dilution of the reactant mixture was enough to stop combustion.

Since in Case \#2, $\mathrm{CH}_{4}$ acted as a pure inert, very similar to $\mathrm{N}_{2}$ in so far as the oxidation process is concerned, and since $\mathrm{N}_{2}$ is already in relatively great abundance due to the injection of air, it can be anticipated that the dilution effect of $\mathrm{CH}_{4}$ cannot alone guarantee quenching. To assess this conjecture, another optimized profile was calculated for Case \#3 with $4 \%$ added $\mathrm{CH}_{4}$, and with all $\mathrm{CH}_{4}$ reactions disabled. These results are shown in Figure 8, now in terms of actual flow rate of air. It is seen that the new air profile is slightly different from Case \#1, but that 
oxidation of the gas mixture can still be achieved. Hence, dilution effects of $\mathrm{CH}_{4}$ alone do not guarantee quenching.

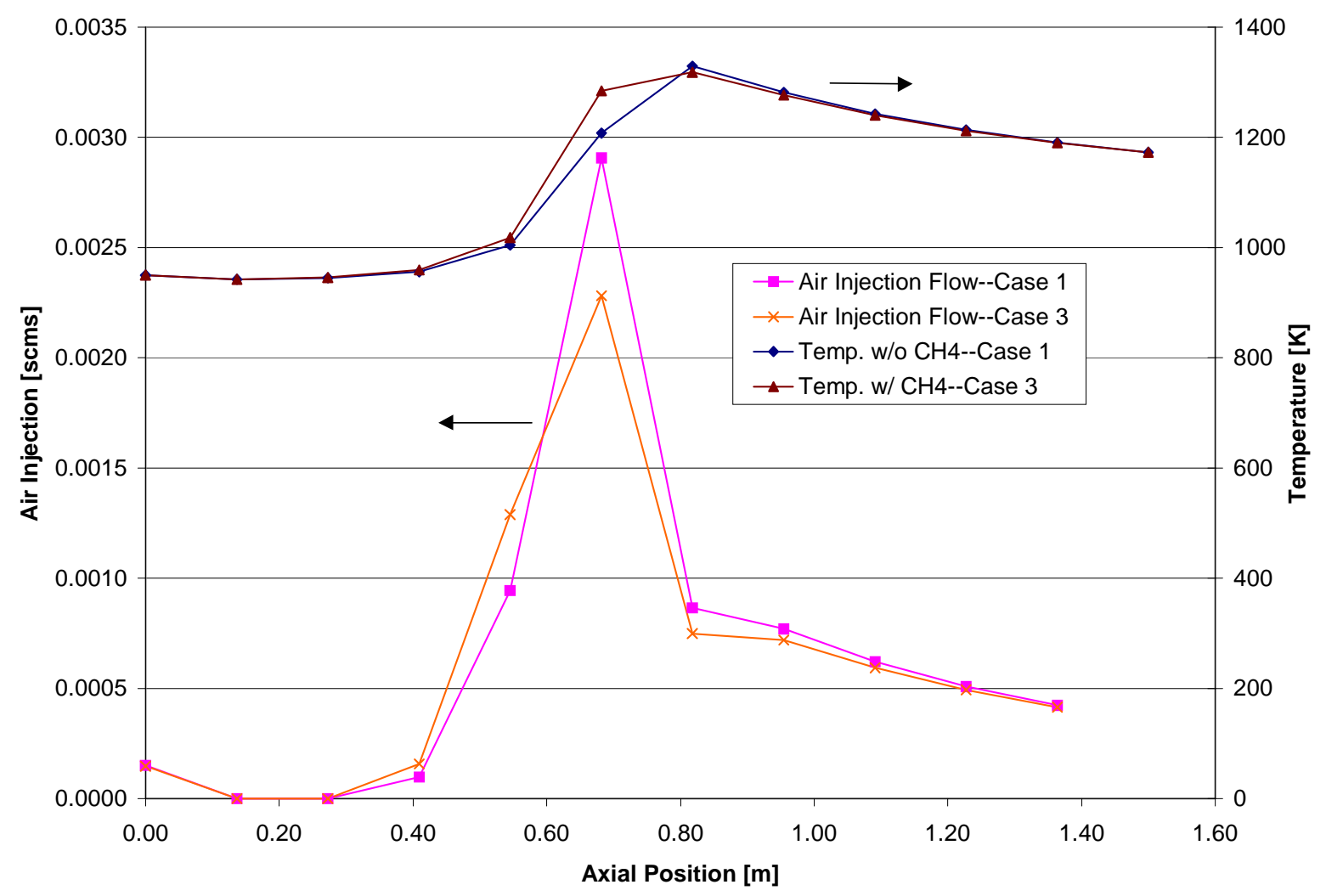

Figure 8. Case \#3 Model Results

(Showing the optimized air profile required for complete oxidation of the anode gas. Four percent $\mathrm{CH}_{4}$ is present, but the $\mathrm{CH}_{4}$ reactions are disabled (methane acting as a diluent only). Results from Case 1 (without $\mathrm{CH}_{4}$ ) also shown for comparison.)

Using the Case \#3 air profile shown in Figure 8, additional combustion calculations were performed in which each of the eight main $\mathrm{CH}_{4}$ reaction equations in the Miller-Bowman set were separately enabled (while all others remained disabled). These calculations allowed the determination of which reaction had the greatest potential to slow down the oxidation of anode gas fuel through interaction with the balance of the Miller-Bowman set. These results are presented in Table 1 where it is shown qualitatively whether or not the reaction causes quenching, and likewise quantitatively by indication of the combustor exit temperature. Also shown in Table 1 are results from a case where all $\mathrm{CH}_{4}$ reactions were disabled (as for case \#3), and for a case where all were enabled. Again, for the case where all were disabled, the oxidation was not quenched, and, as shown in Table 1, the exit temperature is $1173 \mathrm{~K}$. For the case where all reactions were enabled, the oxidation is most strongly quenched, producing an exit temperature of $714 \mathrm{~K}$. As for the individual reactions, the three-body reaction, $\mathrm{CH}_{3}+\mathrm{H}+\mathrm{M}=$ $\mathrm{CH}_{4}+\mathrm{M}$, is apparently weakly supported by the balance of the Miller-Bowman reactions such that it does not significantly affect the overall reaction process. The same is true for the $\mathrm{CH}+$ 
$\mathrm{CH}_{4}=\mathrm{C}_{2} \mathrm{H}_{4}+\mathrm{H}$ reaction. All the other reactions are, acting alone, sufficient enough to cause quenching by the removal of $\mathrm{H}, \mathrm{O}, \mathrm{OH}$, or $\mathrm{HO}_{2}$ radicals. If the exit temperature is used to quantify the "significance" of the given reaction, then the $\mathrm{CH}_{4}+\mathrm{OH}=\mathrm{CH}_{3}+\mathrm{H}_{2} \mathrm{O}_{2}$ reaction has the greatest effect on the overall reaction as it results in the lowest exit gas temperature. Of the reactions that do cause quenching, the one with the least significance is $\mathrm{CH}_{4}+\mathrm{HO}_{2}=\mathrm{CH}_{3}+$ $\mathrm{H}_{2} \mathrm{O}_{2}$.

Table 1. Model results using $4 \% \mathrm{CH}_{4}$ at the inlet to the combustor--all $\mathrm{CH}_{4}$ reactions are disabled unless otherwise noted.

\begin{tabular}{|l|c|c|}
\hline CH4 Reaction Equation Enabled & Oxidation Quenched? (yes/no) & Exit Temperature [K] \\
\hline \multicolumn{1}{|c|}{$\mathrm{None}$ (all disabled) } & $\mathrm{No}$ & 1173 \\
\hline 1) $\mathrm{CH}_{3}+\mathrm{H}+\mathrm{M}=\mathrm{CH}_{4}+\mathrm{M}$ & $\mathrm{No}$ & 1192 \\
\hline 2) $\mathrm{CH}+\mathrm{CH}_{4}=\mathrm{C}_{2} \mathrm{H}_{4}+\mathrm{H}$ & $\mathrm{No}$ & 1172 \\
\hline 3) $\mathrm{CH}_{4}+\mathrm{HO}_{2}=\mathrm{CH}_{3}+\mathrm{H}_{2} \mathrm{O}_{2}$ & Yes & 781 \\
\hline 4) $\mathrm{CH}_{4}+\mathrm{O}=\mathrm{CH}_{3}+\mathrm{OH}$ & Yes & 718 \\
\hline 5) $\mathrm{CH}_{4}+\mathrm{H}=\mathrm{CH}_{3}+\mathrm{H}_{2}$ & Yes & 716 \\
\hline 6) $\mathrm{CH}_{4}+\mathrm{OH}=\mathrm{CH}_{3}+\mathrm{H}_{2} \mathrm{O}$ & Yes & 714 \\
\hline All Enabled & Yes & 714 \\
\hline
\end{tabular}

Table 2. Model results using $4 \% \mathrm{CH}_{4}$ at the inlet to the combustor--all $\mathrm{CH}_{4}$ reactions are enabled unless otherwise noted.

\begin{tabular}{|l|c|c|}
\hline CH4 Reaction Equation Disabled & Oxidation Quenched? (yes/no) & Exit Temperature [K] \\
\hline 1) $\mathrm{CH}_{3}+\mathrm{H}+\mathrm{M}=\mathrm{CH}_{4}+\mathrm{M}$ & Yes & 716.34 \\
\hline 2) $\mathrm{CH}+\mathrm{CH}_{4}=\mathrm{C}_{2} \mathrm{H}_{4}+\mathrm{H}$ & Yes & 714.27 \\
\hline 3) $\mathrm{CH}_{4}+\mathrm{HO}_{2}=\mathrm{CH}_{3}+\mathrm{H}_{2} \mathrm{O}_{2}$ & Yes & 714.27 \\
\hline 4) $\mathrm{CH}_{4}+\mathrm{O}=\mathrm{CH}_{3}+\mathrm{OH}$ & Yes & 714.27 \\
\hline 5) $\mathrm{CH}_{4}+\mathrm{H}=\mathrm{CH}_{3}+\mathrm{H}_{2}$ & Yes & 714.29 \\
\hline 6) $\mathrm{CH}_{4}+\mathrm{OH}=\mathrm{CH}_{3}+\mathrm{H}_{2} \mathrm{O}$ & Yes & 714.27 \\
\hline
\end{tabular}

The above analysis only provides information on how an individual methane reaction affects the overall reaction through the non-methane reactions. To determine any synergy with the other methane reactions, another analysis was performed whereby individual methane reactions were disabled, while the complete balance of the Miller-Bowman set remained enabled. These results are shown in Table 2 where it is found that removing any of the individual reactions will not prevent quenching. Although the differences are small, if the exit temperature is again used to quantify "significance" of the reaction, then it is now found that the three body reaction, $\mathrm{CH}_{3}+$ $\mathrm{H}+\mathrm{M}=\mathrm{CH}_{4}+\mathrm{M}$, has the greatest effect on the reaction process (removing this one equation increases the oxidation rate the most as evidenced by the increased temperature.) The rest of the reactions show very little effect on the exit temperature.

Based on the above analysis, it appears that the quenching occurs most strongly through the removal of $\mathrm{H}$ radicals via reactions 1 and 5 (see tables), where reaction 1 is supported by 
reactions $3,4,5$ and 6 , which require the presence of methane to produce the methyl radical needed by reaction 1 .

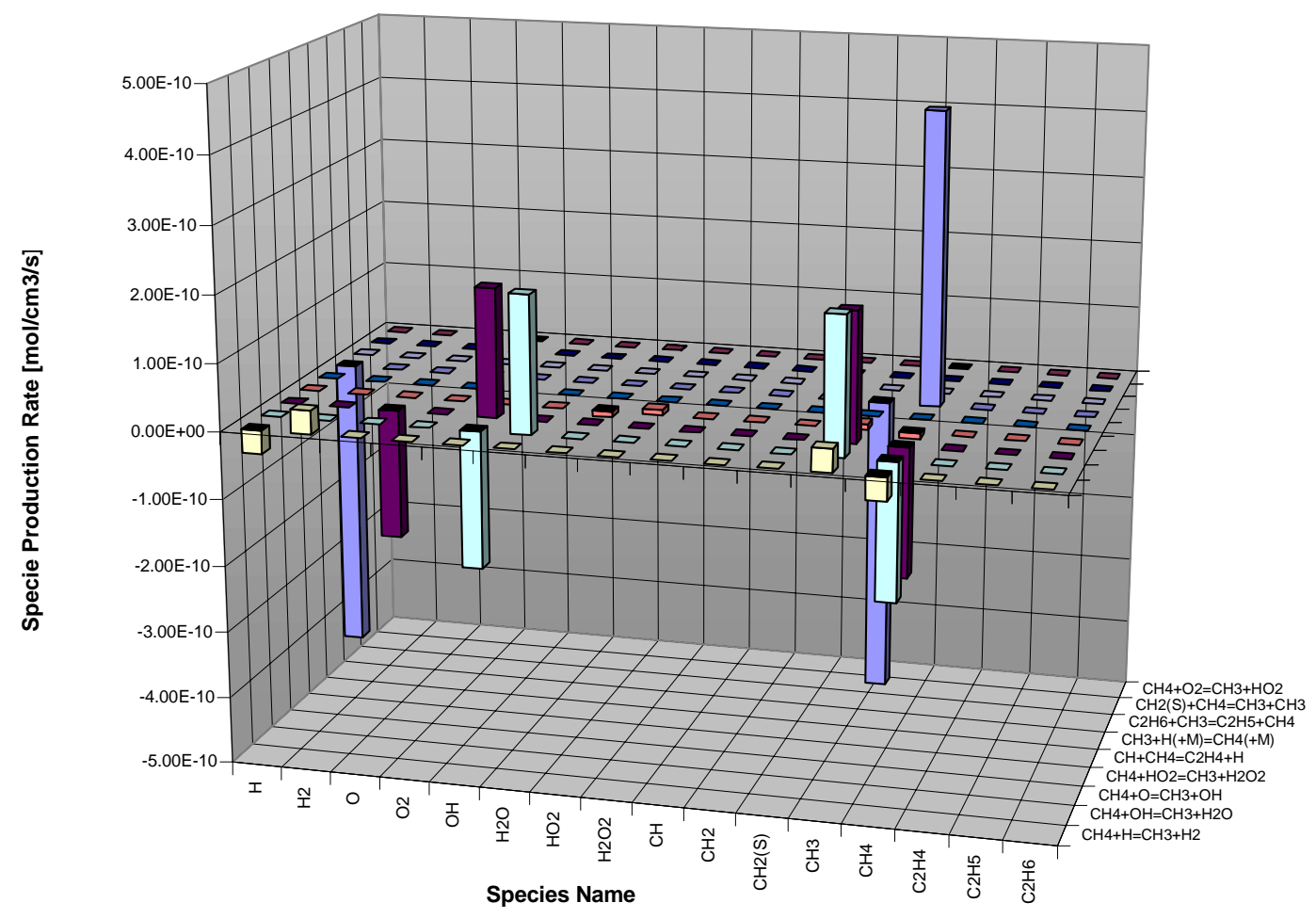

Figure 9. Specie Production Rates for Methane Reactions

(Production rates are dominated by $\mathrm{H}$ and $\mathrm{O}$ radical removal. Methane, hydroxyl, and methyl production and destruction are approximately balanced as shown more clearly in Figure 10.)

In support of these results, Figure 9 shows the specie production rates for all $\mathrm{CH}_{4}$ reactions (at the $5^{\text {th }}$ combustor section), and Figure 10 shows the net production of all the species (for two sections of the combustor, 1 and 5). It is clear that the concentration of the $\mathrm{H}$ radical is strongly reduced by the $\mathrm{CH}_{4}$ reactions. The net effect of reactions $1,3,4,5$, and 6 is to treat methane as a catalyst for $\mathrm{H}$ and $\mathrm{O}$ radical destruction. Since there is only weak production of the methyl radical, it is clear that the three-body reaction is highly efficient at removing any methyl produced by the other methane reactions. 


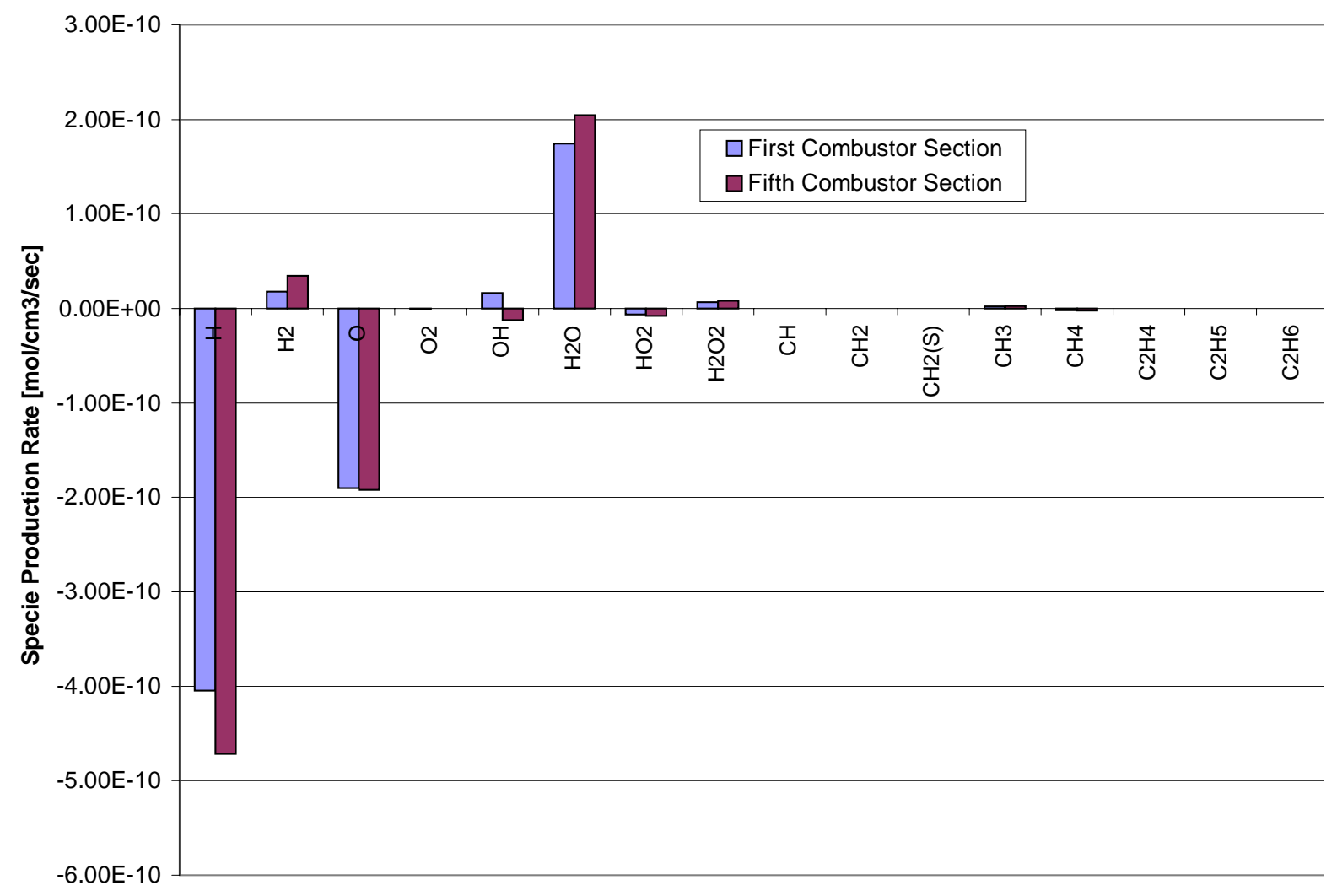

Figure 10. Net Specie Production Rates for Two Combustor Sections

(The net effect of all $\mathrm{CH}_{4}$ reaction equations is a strong destruction of $\mathrm{H}$ and $\mathrm{O}$ atoms.)

\section{Summary}

The main goal of this work is to better understand the oxidation behavior of fuel cell anode exhaust gas. This R\&D goal results from the desire to develop less expensive fuel cell plant systems via gas phase oxidation vs. catalytic oxidation. The present work focused on understanding the effect of natural gas addition on the anode gas oxidation process. It was hoped that improved methods to reliably achieve gas phase oxidation of the anode gas could be identified. It is also understood that these results will also be of value to developers of other fuel cell applications where additional thermal control is desired via addition of fuel energy following the fuel cell.

This work investigated experimentally and numerically the behavior of natural gas addition to an anode gas mixture representative of molten-carbonate fuel cells. It was found that the addition of natural gas to the anode gas mixture caused a quenching of the reactions. Through the use of detailed kinetic modeling, the cause for this behavior was identified to be the increased presence of $\mathrm{CH}_{3}$ that primarily attacks $\mathrm{H}$ and $\mathrm{O}$ radicals, and reduces them to less reactive species. 


\section{References}

Gemmen, R.S. 1997. Oxidation of Low Calorific Value Gases-Applying Optimization Techniques to Combustor Design. Paper presented at the 1998 International Joint Power Generation Conference. August 23-26, Baltimore, MD.

Gemmen, R.S. and E.H. Robey. 1998. A Partial Oxidation Technique for Fuel-Cell Anode Exhaust-Gas Synthesis. DOE Technical Report, DOE/FETC-98/1071.

Kee, R.J., F.M. Rupley, and J.A. Miller. 1989. Chemkin-II: A Fortran Chemical Kinetics Package for the Analysis of Gas-Phase Chemical Kinetics, Sandia National Laboratory Report, SAND89-8009.

Kordesch, K., and G. Simader. 1996. Fuel Cells and Their Applications. VCH Verlagsgesellschaft, New York.

Liese, E.A., R.S. Gemmen, F. Jabbari, and J. Brouwer. 1999. Technical Development Issues and Dynamic Modeling of Gas Turbine and Fuel Cell Hybrid Systems. Paper presented at the 1999 IGTI Conference, June 7-10, Indianapolis, IN. To be published in J. of Engineering for Gas Turbines and Power.

Miller, J.A. and C.T. Bowman. 1989. Mechanism and Modeling of Nitrogen Chemistry in Combustion. Prog. Energy Combust. Sci. 15:287-338.

Mulholland, J.A., A.F. Sarofim, and J.M. Beer. 1992. On the Derivation of Global Ignition Kinetics from a Detailed Mechanism for Simple Hydrocarbon Oxidation. Comb. Sci. and Tech. 87:139-156.

Radhakrishnan, K., and A.C. Hindmarsh. 1993. Description and Use of LSODE, the Livermore Solver for Ordinary Differential Equations. NASA Reference Publication 1327.

Williams, M.C., P.L. Micheli, and E.L. Parsons, Jr. 1995. Engineering a 70 Percent Efficient, Indirect Fired Fuel Cell Bottomed Turbine Cycle. Proceedings of the Fuel Cells 1995 Review Meeting. August, 1995, ed. T.J. George, DOE/METC-95/1020. 